FEMP-2568

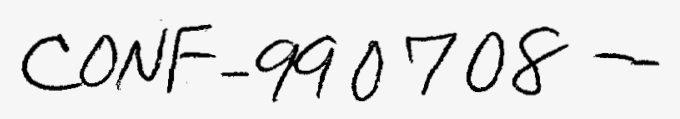

\title{
APPLICATION OF IN-SITU GAMMA SPECTROMETRY IN THE REMEDIATION \\ OF RADIOACTIVELY CONTAMINATED SOIL
}

\section{BY}

Chris Sutton, John D. Yesso, Raymond J. Danahy, Thomas Cox*

Fluor Daniel Fernald, Inc.*

Fernald Environmental Management Project

P.O. Box 538704

Cincinnati, Ohio 45253-8704

FEMED

MAY 17 1 1898

OSTI

For Presentation at the

1999 Waste Testing and Quality Assurance Symposium

Washington, D.C., July 18, 1999

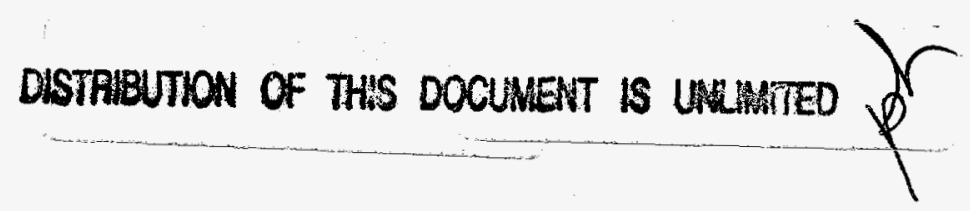

*Fluor Daniel Fernald, Inc. with the U.S. Department of Energy under Contract No. DE-AC24-92OR21972 
This technical information was prepared as an account of work sponsored by an agency of the United States Government. Neither the United States Government or any agencies thereof, nor any of their employees, nor any of its contractors, subcontractors nor their employees make any warranty, express or implied, or assumes any legal liability or responsibility for the accuracy, completeness, or usefulness of any information, apparatus, product, or process disclosed, or represents that its use would not infringe privately owned rights. Reference herein to any specific commercial product, process, or service by trade name, trademark, manufacturer, or otherwise, does not necessarily constitute or imply its endorsement, recommendation, or favoring by the United States Government or any agency thereof. The views and opinions of authors expressed herein do not necessarily state or reflect those of the United States Government or any agency thereof, or Fluor Daniel Fernald, its affiliates or its parent companies. 


\section{DISCLAIMER}

Portions of this document may be illegible in electronic image products. Images are produced from the best available original document. 


\section{APPLICATION OF IN-SITU GAMMA SPECTROMETRY IN THE REMEDIATION OF RADIOACTIVELY CONTAMINATED SOIL}

Chris Sutton, Senior Technical Expert, John D. Yesso, Senior Technical Expert, Raymond J. Danahy, Environmental Scientist, and Thomas Cox, Environmental Scientist, Soil and Water Division, Fluor Daniel Fernald, P.O. Box 538704, Cincinnati, Ohio, 45253-8704, chris_sutton@fernald.gov

\section{ABSTRACT}

The Fernald Environmental Management Project (FEMP) is a U.S. Department of Energy site that is undergoing total remediation and closure. Most of the remediation effort entails massive excavation of soil for disposal, both offsite and onsite, at an engineered disposal facility. In-situ gamma spectrometry is routinely used to support soil excavation operations to accurately and quickly identify soil areas as being above or below regulatory remediation criteria.

Two different in-situ gamma spectrometry systems are used. The first is a sodium iodide (Nal) detector mounted either on a tractor or a jogging stroller, depending on the terrain to be measured. The Nal system allows the collection of a gamma energy spectrum which can be analyzed to identify and quantify radioactive isotopes which are present within the detector's viewing area. Each energy spectrum is tagged by location coordinates provided by an on-board global positioning system (GPS) to precisely locate elevated contamination areas. The second is a tripod-mounted, high purity germanium detector (HPGe) gamma spectrometry system that is functionally similar to the $\mathrm{Nal}$ system. The principal advantage of the HPGe is its superior resolution, which allows much more accurate identification and quantification of radionuclide contaminants in soils.

In order to effectively utilize the data quality objective process with these systems, three quality assurance (QA) elements had to be performed. First, method validation studies demonstrated comparability with conventional radiochemistry methods and established performance-based acceptance criteria for key quality control parameters at various data quality levels. The method validation studies for the HPGe system stressed accuracy and comparability, while method validation studies for the $\mathrm{Nal}$ systems stressed quantifying measurement uncertainty and detection limits. Second, a "User's Manual" was developed that specifies measurement approaches, provides data interpretation guidelines, and discusses operational and environmental factors that could adversely affect in-situ gamma spectrometry measurements. This manual is primarily designed for environmental scientists responsible for remediating soils rather than for analytical chemists who perform the measurements. Third, an in-situ gamma spectrometry QA program was implemented to address programmatic QA elements, to ensure legal defensibility of the data, and to specify quality control (QC) criteria, their frequency of measurement, their acceptance limits and whether or not they are to be control charted.

\section{INTRODUCTION}

The FEMP is a U.S. Department of Energy site that is undergoing total remediation and closure. Most of the remediation effort entails massive excavation of soil for disposal, both offsite and onsite at an engineered disposal facility. In-situ gamma spectrometry is routinely used in support of soil excavation operations to accurately and quickly identify soil areas as being above or below regulatory remediation criteria. Two different in-situ gamma spectrometry systems are used. The first is a sodium iodide (Nal) detector system, while the second is a high-purity germanium (HPGe) detector system. The former system is mounted on either a tractor (RTRAK) or a jogging stroller (RSS), depending on the terrain, while the latter system is tripod-mounted. 
Both RSS and RTRAK have a measurement system consisting of a $4 \times 4 \times 16$ inch Nal detector and associated electronics to provide high-speed pulse height analysis. This system allows the collection of a gamma ray energy spectrum, which can be analyzed to identify and quantify radioactive isotopes that may be present within the detector's viewing area. The RTRAK and RSS are each equipped with a GPS operated in a real-time differential mode to provide location coordinates. Each energy spectrum is tagged with the location coordinates provided by the GPS. All energy and location data are stored on magnetic media by an on-board computer system. This information is used to accurately locate and subsequently map radiological data within the measurement area.

On the RTRAK, the detector is positioned on the tractor horizontal to the ground and perpendicular to the direction of travel at a height of approximately $31 \mathrm{~cm}$ above the ground. The detector on the RSS is mounted horizontal to the ground and parallel to the direction of travel at a height of approximately $31 \mathrm{~cm}$. The normal operation of the RTRAK and RSS consists of moving the systems over the measurement area at a predetermined speed. Spectra are continuously collected at regular intervals, typically a few seconds. The viewing area size is a function of the tractor speed, the acquisition time, and the detector's geometrical configuration. For example, for the $4 \times 4 \times 16$ inch detector at the $31 \mathrm{~cm}$ height, the viewing area is $8.8 . \mathrm{m}^{2}$ for a single measurement when the system is moving at one mile per hour, with a 4-second data acquisition time (typical operating parameters).

The HPGe detectors are mounted on tripods at heights ranging from $15 \mathrm{~cm}$ to $1.0 \mathrm{~m}$ above the ground surface. The detectors are connected to 8192 channel multi-channel analyzers which allow the collection of a high resolution gamma ray spectrum. The superior resolution of HPGe detectors relative to $\mathrm{Nal}$ detectors allow it to accurately quantify a wide variety of isotopes with minimal interferences. Data acquisition times typically are 15 minutes. The HPGe field of view ranges from over $100 \mathrm{~m}^{2}$ at a $1.0 \mathrm{~m}$ detector height to $3.1 \mathrm{~m}^{2}$ at a $15 \mathrm{~cm}$ detector height.

\section{METHOD VALIDATION STUDIES}

The method validation study for HPGe entails determining the similarity between data generated by HPGe measurements and data generated by laboratory analysis of physical samples. It also delineates acceptance criteria for key $Q C$ elements and data quality elements. Three radiological contaminants of concern were measured by HPGe and laboratory methods: total uranium, thorium232 and radium-226. Method validation studies for Nal systems stressed quantifying measurement uncertainty and detection limits. Such assessments were performed as a function of vehicle speed and data acquisition time in order to determine preferred operating parameters.

\section{HPGe Comparability Studies}

One part of the method validation study for HPGe entailed assessing the comparability between HPGe measurements and laboratory data. To accomplish this, a series of physical samples were collected from different areas of widely varying concentrations of contaminants. In each area, samples were collected in a "bullseye" pattern to mimic the averaging done by the field HPGe detector. That is, the area from which physical samples were taken can be envisioned as a circle, with the HPGe detector located above the center. The HPGe detector records gamma ray photons from every point within the circle; however, it records more gamma rays from soil closer to the detector than from soil further from the detector.

For comparison with HPGe measurements, a weighted average (weighted based upon gamma photon fluence contributions) of all laboratory data for a given area was calculated. Figures 1 and 2 show plots of HPGe measurements vs weighted average laboratory data for total uranium and 
thorium-232. High correlation coefficients $\left(R^{2}\right.$ value), line slopes near one, and line intercepts close to 0.0 demonstrate comparability of data. The width of the error bars for laboratory data in Figures 1 and 2 primarily reflect the degree of heterogeneity among samples in a given area rather than laboratory precision.

\section{Nal Method Validation}

A major portion of the method validation studies for Nal systems addressed the total system measurement uncertainty for moving systems. Data were acquired experimentally via repeated measurement profiles, which involved moving the RTRAK or RSS back and forth along a given track for 20 iterations. Each track was divided into segments and the mean and standard deviation of the measurements in each segment was determined. Table 1 shows the results of the precision studies for one area with the RTRAK moving at a speed for $0.5 \mathrm{mph}$, with a 2-second data acquisition time. Such precision studies were carried out in different areas, using a combination of different speeds and data acquisition times in each area. The results of these studies demonstrated that:

1. The uranium-238 measurements display low degrees of precision. This limits the usability of the data for low-concentration measurements. The low degree of precision (high uncertainty) occurs because of the low photon yield at the energy of interest, the high spectrum background, and interferences from thorium-232 and radium-226 daughter gamma rays.

2. The thorium-232 measurements display the highest degree of precision of the three radionuclides of interest. The high degree of precision (small uncertainty) occurs because of a relatively high photon yield at the energy of interest, the low spectrum background, and because of only limited interference from a low intensity radium-226 peak.

3. The radium-226 measurements display a degree of precision similar to that of uranium or between that of the other two radionuclides of interest. This is in part because both the photon yield and the detection efficiency at the energy of interest fall between those of the thorium and uranium.

Knowledge of the overall precision from studies such as the one outlined above was a key factor in ascertaining a priori minimum detectable concentrations, determining error rates, and setting trigger levels.

\section{USER'S MANUAL}

Early in the remediation process at the FEMP, it became clear that a critical need existed to bridge the gap between primarily analytical information contained in method validation studies and programmatic remediation design documents. The User's Manual bridges that gap by providing user guidelines, data interpretation guidelines, and measurementstrategies and approaches; by discussing operational and technical factors that could adversely affect data; and by delineating strengths and limitations of in-situ gamma spectrometry. While the document is beneficial to anyone involved with any aspect of in-situ gamma spectrometry, it is primarily aimed toward FEMP project personnel who:

- $\quad$ plan soil remediation projects;

- $\quad$ collect in-situ gamma spectrometry data for soil remediation projects;

- $\quad$ interpret in-situ gamma spectrometry data for soil remediation projects;

- $\quad$ integrate in-situ gamma spectrometry data with other data sets or into engineering designs; and 
- make decisions based upon in-situ gamma spectrometry data.

The User's Manual has four sections: 1) Investigation Approaches; 2) Measurement Approaches; 3) Data Interpretation Guidelines; and 4) Technical Issues. Section 1 deals with broader-scale issues such as how in-situ gamma spectrometry is used in pre-design investigations and in soil excavation operations. Section 2 deals with smaller-scale issues such as how in-situ gamma spectrometry is used to detect, confirm, and identify hot spots. Section 3 addresses such issues as climatic/weather effects upon in-situ gamma measurements, topographic effects, total activity data interpretation, and mapping conventions. Section 4 addresses technical issues such as data review checklists, minimum detectable concentrations, positioning and surveying, and the effects of radon-222 on radium-226 measurements.

\section{QUALITY CONTROL/QUALITY ASSURANCE}

All in-situ gamma spectrometry operations, whether method validation studies or field measurements in support of remediation operations, are governed by a comprehensive QAVQC program. The QA program contains all of the same quality elements as a traditional environmental laboratory $Q A$ program. It has ten criteria: 1) QA program; 2) personnel training/qualification; 3) quality improvement; 4) documents and records; 5) work processes; 6) method design, 7) procurement/control of materials and services; 8) facilities and equipment/calibration and maintenance; 9) management assessment; and 10) external assessments and audits.

Of particular interest is the QC program, which is centered around performance-based measurements. In this regard, acceptance criteria of key quality control elements are specified, while the mechanism of how such measurements are obtained are not specified in either the QA plan or QC plans. Table 2 contains such criteria for two data quality levels called Analytical Support Levels (ASLs) at the FEMP. ASL B corresponds generally to the US EPA "screening data" category, while ASL D corresponds to the US EPA's "definitive data" category.

Information from the method validation studies, the User's Manual, and the QA/QC plans are incorporated into Project Specific Plans (PSPs) and project Data Quality Objectives (DQOs) to support specific remediation activities. In-situ gamma spectrometry data are validated to ensure that they satisfy the requirements and needs specified by the PSPs and DQOs.

\section{SUMMARY}

Routine utilization of in-situ gamma spectrometry in remediation at Fernald rests upon three programmatic elements. method validation studies carried out to delineate key measurement quality control elements such as comparability, representativeness, accuracy, uncertainty, and detection limits; a User's Manual which specifies to environmental engineers and scientists how in-situ gamma spectrometry should be used in remediation operations; and a comprehensive QA program to ensure that in-situ gamma spectrometry data are of sufficient quality for their intended usage and are legally defensible. 
TABLE 1

RTRAK PRECISION STUDIES AT 0.5 MPH WITH A 2.0 SECOND DATA ACQUISITION TIME

\begin{tabular}{|c|c|c|c|c|c|c|c|c|c|c|}
\cline { 3 - 12 } & \multicolumn{2}{c}{} & \multicolumn{2}{c|}{ Uranium-238 (pCi/g) } & \multicolumn{2}{c|}{ Thorium-232 (pCi/g) } & \multicolumn{3}{c|}{ Radium-226 (pCi/g) } \\
\hline Segment & $\begin{array}{c}\text { No. } \\
\text { Measurements }\end{array}$ & Mean & Std Dev & \%Std Dev & Mean & Std Dev & \%Std Dev & Mean & Std Dev & \%Std Dev \\
\hline 01 & 129 & 12.4 & 9.3 & 75 & 0.75 & 0.26 & 35 & 0.72 & 0.50 & 70 \\
\hline 02 & 217 & 14.1 & 9.1 & 65 & 0.77 & 0.32 & 42 & 0.79 & 0.51 & 64 \\
\hline 03 & 206 & 15.6 & 9.0 & 58 & 0.75 & 0.27 & 36 & 0.82 & 0.47 & 57 \\
\hline 004 & 205 & 15.2 & 8.3 & 55 & 0.80 & 0.31 & 39 & 0.76 & 0.53 & 70 \\
\hline 05 & 216 & 16.8 & 8.7 & 52 & 0.73 & 0.29 & 40 & 0.82 & 0.54 & 66 \\
\hline 06 & 225 & 14.5 & 9.4 & 65 & 0.76 & 0.29 & 38 & 0.76 & 0.52 & 68 \\
\hline ROAD & 120 & 12.2 & 7.3 & 60 & 0.48 & 0.29 & 60 & 0.59 & 0.45 & 76 \\
\hline 08 & 231 & 17.0 & 9.2 & 54 & 0.75 & 0.34 & 45 & 0.82 & 0.59 & 72 \\
\hline 09 & 232 & 18.0 & 9.3 & 51 & 0.75 & 0.32 & 43 & 0.87 & 0.51 & 58 \\
\hline 10 & 240 & 17.2 & 9.8 & 57 & 0.73 & 0.31 & 42 & 0.77 & 0.48 & 63 \\
\hline 11 & 193 & 15.2 & 8.6 & 56 & 0.75 & 0.28 & 37 & 0.76 & 0.50 & 65 \\
\hline Averages & & 15.7 & 9.1 & 59 & 0.76 & 0.30 & 40 & 0.79 & 0.52 & 66 \\
\hline Minimum & & 12.4 & 8.3 & 51 & 0.48 & 0.26 & 35 & 0.72 & 0.45 & 57 \\
\hline Maximum & & 18.0 & 9.8 & 75 & 0.80 & 0.34 & 60 & 0.87 & 0.59 & 76 \\
\hline
\end{tabular}


TABLE 2

TABULATION OF QUALITY CONTROL CRITERIA AND REQUIREMENTS

\section{RTRAK and RSS Nal Detector QC Criteria and Requirements}

\begin{tabular}{|c|c|c|c|c|c|}
\hline QC Element & Nuclide & $\begin{array}{l}\text { Gamma } \\
\text { Energy }\end{array}$ & QC Criteria & Frequency & $\begin{array}{c}\text { Control } \\
\text { Chart }\end{array}$ \\
\hline $\begin{array}{l}\text { Energy } \\
\text { Calibration }\end{array}$ & $\begin{array}{c}\mathrm{T} 1-208 \\
\mathrm{~Pb}-212\end{array}$ & $\begin{array}{l}2614.5 \mathrm{keV} \\
238.6 \mathrm{keV}\end{array}$ & $\begin{array}{c}\text { Channel } 447 \pm 2 \\
\text { Channel } 40 \pm 2\end{array}$ & $\begin{array}{l}\text { Days used, prior to } \\
\text { and following use }\end{array}$ & No \\
\hline $\begin{array}{c}\text { Detector } \\
\text { Counting } \\
\text { Efficiency Check }\end{array}$ & TI-208 & $2614.5 \mathrm{keV}$ & $\begin{array}{l}\text { Predetermined check } \\
\text { source value (decay } \\
\text { corrected) } \\
\bar{x} \pm 3 \text { sigma }\end{array}$ & $\begin{array}{l}\text { Days used, prior to } \\
\text { and following use }\end{array}$ & Yes \\
\hline
\end{tabular}

\section{HPGe Detector QC Criteria and Requirements}

\begin{tabular}{|c|c|c|c|c|c|}
\hline $\begin{array}{c}\text { QC } \\
\text { Element }\end{array}$ & Nuclide & $\begin{array}{l}\text { Gamma } \\
\text { Energy }\end{array}$ & QC Criteria & Frequency & $\begin{array}{c}\text { Control } \\
\text { Chant }\end{array}$ \\
\hline $\begin{array}{l}\text { Energy } \\
\text { Calibration }\end{array}$ & $\begin{array}{c}\text { Am-241 } \\
\text { Cs-137 } \\
\text { Co-60 }\end{array}$ & $\begin{array}{c}59.5 \mathrm{keV} \\
661.6 \mathrm{keV} \\
1332.5 \mathrm{keV}\end{array}$ & $\begin{array}{l}\text { Channel } 158 \pm 1 \\
\text { Channel } 1763 \pm 2 \\
\text { Channel } 3553 \pm 3\end{array}$ & $\begin{array}{l}\text { Days used, prior to and } \\
\text { following use }\end{array}$ & No \\
\hline $\begin{array}{l}\text { Detector } \\
\text { Resolution }\end{array}$ & Co-60 & 1332.5 & $\begin{array}{l}\text { Measured mean value } \\
\tilde{x} \pm 3 \text { sigma }\end{array}$ & $\begin{array}{l}\text { Days used, prior to and } \\
\text { following use }\end{array}$ & Yes \\
\hline $\begin{array}{l}\text { Detector } \\
\text { Counting } \\
\text { Efficiency } \\
\text { Check }\end{array}$ & $\mathrm{Co}-60$ & 1332.5 & $\begin{array}{l}\text { pre-determined check } \\
\text { source value (decay } \\
\text { corrected) } \\
\bar{x} \pm 3 \text { sigma }\end{array}$ & $\begin{array}{l}\text { Days used, prior to and } \\
\text { following use }\end{array}$ & Yes \\
\hline
\end{tabular}

\section{HPGe Field Measurements QC Criteria and Requirements}

\begin{tabular}{|c|c|c|c|c|}
\hline QC Element & $\begin{array}{c}\text { Gamma } \\
\text { Energy } \\
\text { Nuclide or } \\
\text { Basis }\end{array}$ & $\begin{array}{c}\text { QC Acceptance } \\
\text { Criteria }\end{array}$ & Frequency & $\begin{array}{c}\text { Control } \\
\text { Chart }\end{array}$ \\
\hline $\begin{array}{l}\text { Field } \\
\text { Measurement } \\
\text { Interference }\end{array}$ & $1460.8 \mathrm{keV}$ & $\begin{array}{c}k e V=1460.8 \\
F W H M \leq 3.0 \mathrm{keV} \\
\text { or } \\
\text { Channel }=3895.0 \\
\text { FWHM } \leq 8 \text { Channels }\end{array}$ & $\begin{array}{l}\text { Each time } \\
\text { measurements are } \\
\text { made }\end{array}$ & No \\
\hline $\begin{array}{l}\text { Field Control } \\
\text { Station }\end{array}$ & $\begin{array}{l}\text { Total U } \\
\text { Th-232 } \\
\text { Ra-226 } \\
\mathrm{K}-40\end{array}$ & $\begin{array}{l}\text { ASL }-D \\
\text { measured value } \pm 3 \text { sigma } \\
\text { measured value } \pm 3 \text { sigma } \\
\text { measured value } \pm 3 \text { sigma } \\
\text { measured value } 3 \text { sigma }\end{array}$ & $\begin{array}{l}\text { On each day } \\
\text { measurements are } \\
\text { made }\end{array}$ & Yes \\
\hline $\begin{array}{l}\text { Field Control } \\
\text { Station }\end{array}$ & $\begin{array}{l}\text { Temperature } \\
\text { Humidity } \\
\text { Soll Moisture }\end{array}$ & No Criteria & $\begin{array}{l}\text { Each day } \\
\text { measurements are } \\
\text { made }\end{array}$ & No \\
\hline
\end{tabular}




\begin{tabular}{|c|c|c|c|c|}
\hline QC Element & $\begin{array}{c}\text { Gamma } \\
\text { Energy } \\
\text { Nuclide or } \\
\text { Basis } \\
\end{array}$ & $\begin{array}{c}\text { QC Acceptance } \\
\text { Criteria }\end{array}$ & Frequency & $\begin{array}{c}\text { Control } \\
\text { Chart }\end{array}$ \\
\hline $\begin{array}{c}\text { Minimum } \\
\text { Detectable } \\
\text { Concentration }\end{array}$ & $\begin{array}{c}\text { Free Release } \\
\text { Levels for } \\
\text { Nuclides } \\
\text { of Concern }\end{array}$ & $\begin{array}{c}\text { For ASL-D } \\
95 \% \text { UCL }{ }^{1}<\text { FRLs } \\
\text { For ASL-B } \\
90 \% \text { UCL }{ }^{1}<\text { FRLs }\end{array}$ & Quarterly & No \\
\hline $\begin{array}{l}\text { Measurement } \\
\text { Accuracy }\end{array}$ & $\begin{array}{l}\text { Compared to } \\
\text { weighted average } \\
\text { of physical } \\
\text { samples }\end{array}$ & $\begin{array}{l}\text { ASL-D - weighted average } \\
\text { of physical sample } \pm 20 \% \\
\text { ASL-B - weighted average } \\
\text { of physical sample } \pm 35 \%\end{array}$ & Annually & No \\
\hline $\begin{array}{l}\text { Measurement } \\
\text { Bias }\end{array}$ & $\begin{array}{l}\text { Compared to } \\
\text { weighted average } \\
\text { of physical } \\
\text { samples }\end{array}$ & $\begin{array}{l}\text { Bias acceptable unless it } \\
\text { produces errors resulting in } \\
\text { accuracy being exceeded }\end{array}$ & Annually & No \\
\hline $\begin{array}{l}\text { Precision of } \\
\text { Duplicates }\end{array}$ & $\begin{array}{c}\text { At least one per } \\
\text { every } \\
20 \mathrm{HPGe} \\
\text { measurements. }\end{array}$ & $\begin{array}{l}\text { measured value }>(5 x \\
\text { MDC) } \\
\text { then RPD } \leq \pm 20 \% \\
\text { measured value }<(5 x \\
\text { MDC }) \\
\text { then measurement } \\
\text { difference } \leq \pm M D C\end{array}$ & $\begin{array}{l}\text { At least one per every } \\
20 \mathrm{HPGe} \\
\text { measurements. }\end{array}$ & No \\
\hline $\begin{array}{l}\text { Detector } \\
\text { Counting } \\
\text { Efficiency } \\
\text { Determination }\end{array}$ & $\begin{array}{c}\text { Determination of } \\
\text { conversion } \\
\text { (efficiency) } \\
\text { factors. }\end{array}$ & $\begin{array}{l}\text { initial conversion factor } \\
\pm 10 \% \text { for each gamma } \\
\text { energy }^{2}\end{array}$ & Annually & No \\
\hline
\end{tabular}

Note 1. Upper confidence level (UCL) for MDC.

Note 2. Nuclide and Gamma energies measured:

$\begin{array}{ll}\text { Cs-137 } & 32.2 \\ \text { Eu-152 } & 39.5 \\ \text { Am-241 } & 59.5 \\ \text { Eu-152 } & 121.8 \\ \text { Eu-152 } & 244.7 \\ \text { Eu-152 } & 344.3 \\ \text { Eu-152 } & 411.1 \\ \text { Eu-152 } & 444.0 \\ \text { Cs-137 } & 661.6 \\ \text { Eu-152 } & 778.9 \\ \text { Eu-152 } & 964.0 \\ \text { Co-60 } & 1173.7 \\ \text { Co-60 } & 1332.5 \\ \text { Eu-152 } & 1408.0\end{array}$


Figure 1

Correlation Between HPGe and Laboratory

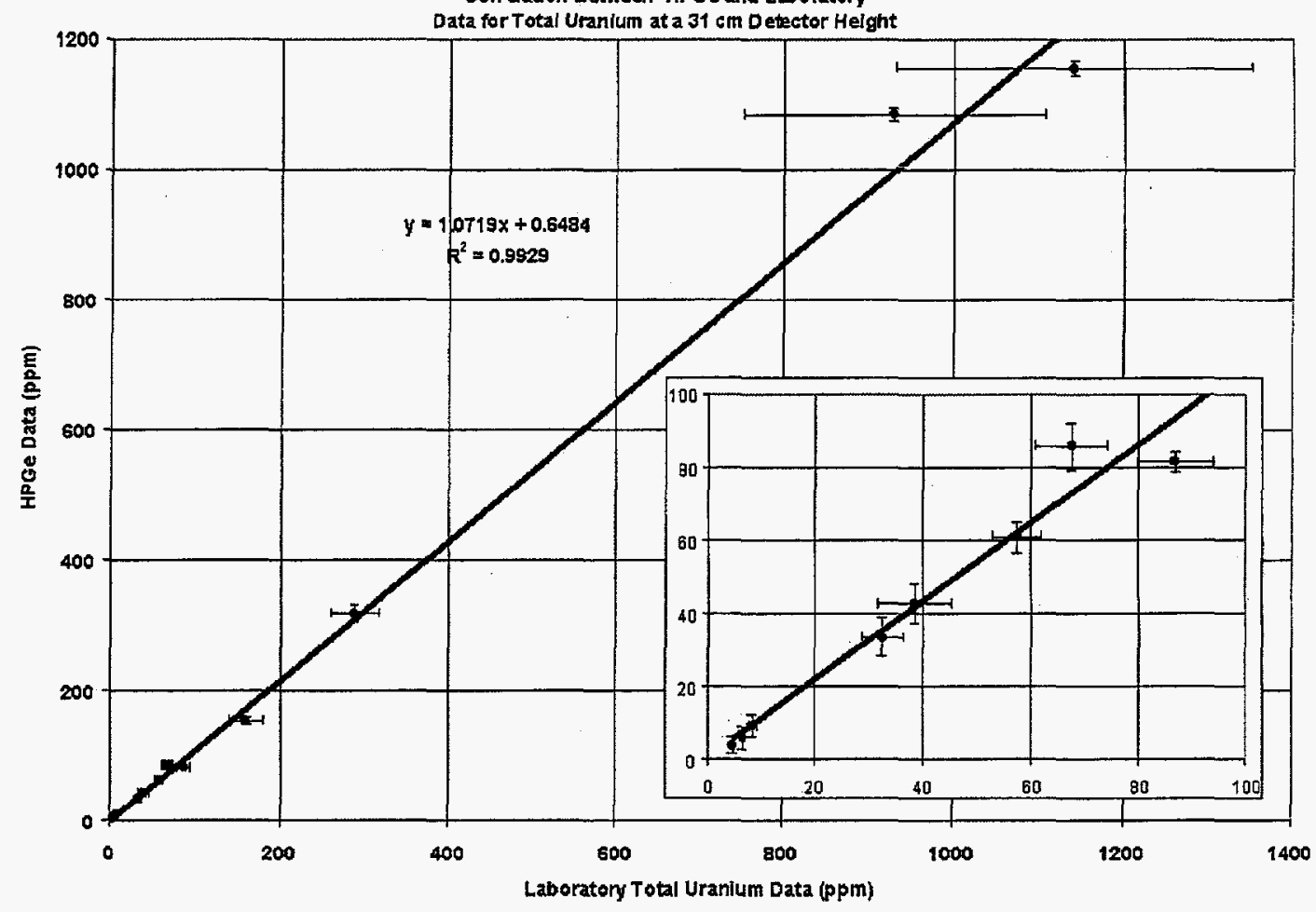

Flgure 2

Correlation 8 etween HP Ge and Lab oratory Data for Th-232

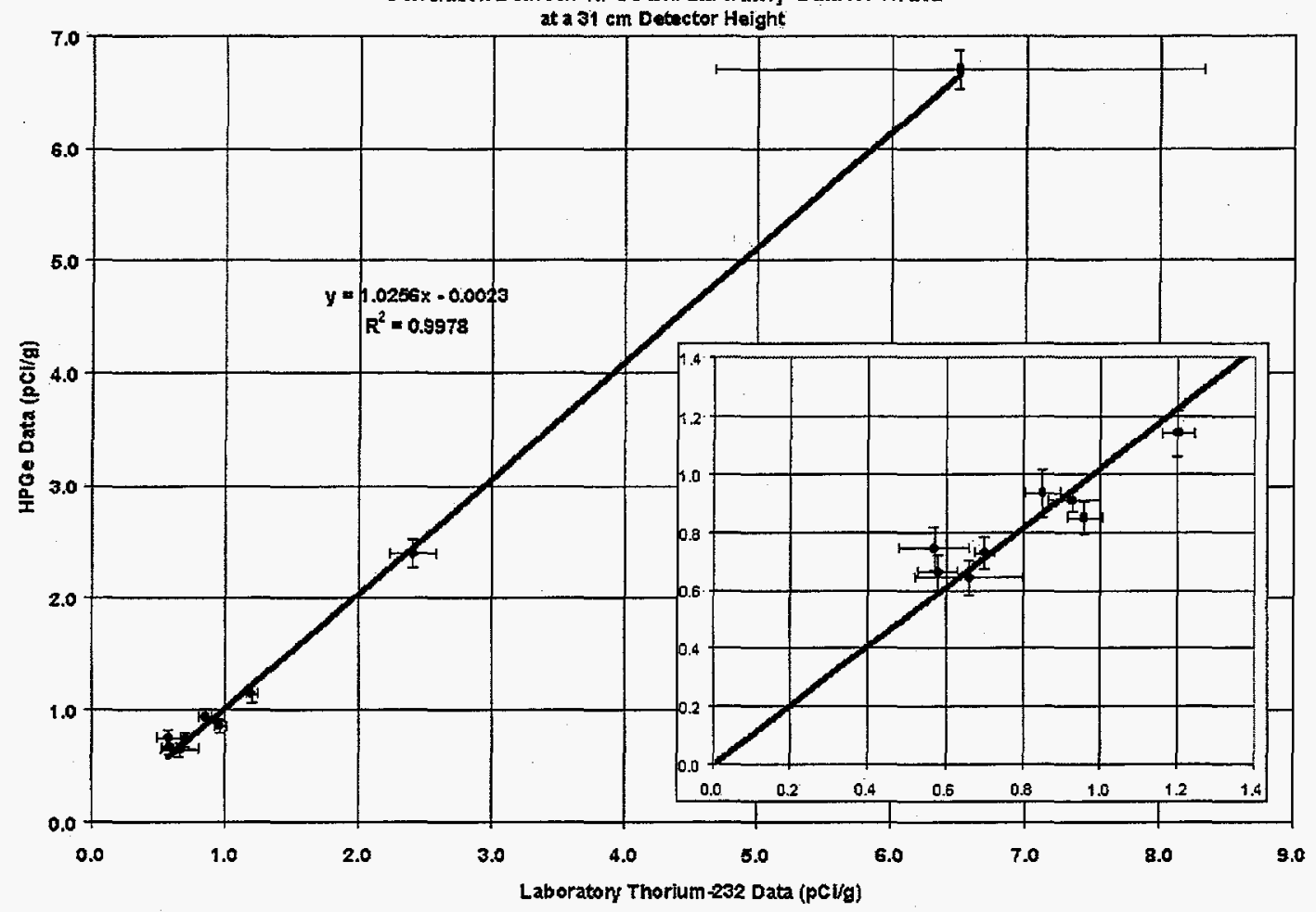

